The definitive version is available at www.blackwell-synergy.com

\title{
Production of exopolysaccharides by Antarctic marine bacterial isolates
}

\author{
C.A. Mancuso Nichols ${ }^{1 \star}$, S. Garon ${ }^{2}$, J.P. Bowman ${ }^{1}$, G. Raguénès ${ }^{2}$ and J. Guézennec ${ }^{2}$ \\ ${ }^{1}$ School of Agricultural Science, University of Tasmania, Hobart, Tasmania, Australia, and \\ ${ }^{2}$ Institute Français de Recherche pour l'Exploitation de la Mer, Centre de Brest, Plouzané, France \\ *: C.A. Mancuso Nichols, School of Agricultural Science, University of Tasmania, GPO Box 252-54, Hobart 7000, \\ Australia (e-mail: c.a.mancuso@utas.edu.au). :
}

\begin{abstract}
This study was undertaken to examine and characterize Antarctic marine bacterial isolates and the exopolysaccharides (EPS) they produce in laboratory culture.

Methods and Results: Two EPS-producing bacterial strains CAM025 and CAM036 were isolated from particulate material sampled from seawater and sea ice in the southern ocean. Analyses of $16 \mathrm{~S}$ rDNA sequences placed these isolates in the genus Pseudoalteromonas. In batch culture, both strains produced EPS. The yield of EPS produced by CAM025 was 30 -fold higher at -2 and $10^{\circ} \mathrm{C}$ than at $20^{\circ} \mathrm{C}$. Crude chemical analyses showed that these EPS were composed primarily of neutral sugars and uronic acids with sulphates. Gas chromatographic analysis of monosaccharides confirmed these gross compositional findings and molar ratios of monosaccharides revealed differences between the two EPS.
\end{abstract}

Conclusions: The EPS produced by Antarctic bacterial isolates examined in this study appeared to be polyanionic and, therefore, 'sticky' with respect to cations such as trace metals.

Significance and Impact of the Study: As the availability of iron as a trace metal is of critical importance in the southern ocean where it is know to limit primary production, the role of these bacterial EPS in the Antarctic marine environment has important ecological implications.

Keywords: Antarctic marine bacteria, exopolysaccharides, particulate organic material, Pseudoalteromonas spp., sea ice. 


\section{INTRODUCTION}

The production of exopolysaccharides (EPS) by bacteria in natural systems has been described as a strategy for growth (Costerton 1999). Studies of bacteria growing in aquatic systems, such as marine sediments, aggregates and detrital particles, show that nearly all the cells are surrounded by EPS (Decho 1990, Costerton 1999) and many of these cells are enclosed with adherent biofilms (White 1986).

In the oceans, EPS exuded by phytoplankton and bacteria coalesce to form transparent exopolymer particles (TEP), which range in size from microns to hundreds of microns (Sullivan and Palmisano 1984, Passow and Alldredge 1994). The aggregation of TEP, phytoplankton, bacteria, faecal pellets, zooplankton and other organic debris form larger particles $(>0.5 \mathrm{~mm}$ in diameter), which are known as marine snow (Fowler and Knauer 1986). Marine snow has been shown to include highly concentrated and diverse microbial communities Rath et al. (1998) engaged in photosynthesis, microbial decomposition (Biddanda 1988) and remineralization of carbon at elevated levels relative to the surrounding sea water (Smith et al. 1992). Marine snow particles therefore make a significant contribution to carbon cycle in the euphotic zone and to the 'biological pump', which transports fixed carbon to deep waters (Alldredge 2000).

Microbial communities have been found associated with deep-sea hydrothermal vents. These ecosystems are characterised by extremely high temperatures and pressures as well as high concentrations of toxic elements (e.g. sulphides and heavy metals). EPS-producing thermophilic and 
mesophilic strains have been isolated from vent environments. Several bacterial exopolymers were found to be novel with significant biotechnological potential (Guezennec et al. 1994).

In the Antarctic marine environment, annual sea-ice is a microhabitat form a complex community of marine bacteria often in close association phytoplankton. These assemblages are essential components of carbon and energy transfers in the Southern Ocean (Sullivan and Palmisano 1984). Abundant bacterial populations have been found in thick annual pack ice with psychrophilic bacteria being particularly common in samples of brown ice and pore waters (Delille 1992). Bacterially produced EPS may provide a means by which bacteria can adhere to the microalgal cells (Sullivan and Palmisano 1984). During ice formation microalgal cells are scavenged by sea-ice crystals floating up to the sea surface (Gleitz and Thomas 1993) and bacteria attached to algal cells may be incorporated into new ice in conjunction with some algal species (Grossmann and Dieckmann 1994).

Studies of both the Arctic (Krembs and Engel 2001) and Antarctic (Sullivan and Palmisano 1984) sea-ice communities suggest that exopolymer production by both phytoplankton and bacteria make a significant contribution to organic carbon in the sea-ice and ice-water interface. Sea-ice bacteria maintained in laboratory culture are reported to secrete copious amounts of mucous (Helmke and Weyland 1995). Little is known about EPS produced by Antarctic marine bacteria or about its role in this extreme environment. In this study, bacterial strains were isolated from the Antarctic marine environment. Two of these isolates and the EPS they produce were examined and results are presented. The authors of this study suggested the fungal EPS could 
provide a cryoprotective role in the harsh Antarctic environment where the availability of liquid water and temperatures are extremely low.

\section{MATERIALS AND METHODS}

\section{Isolation of bacteria}

Samples were obtained during the November/December 2001 voyage of RSV Aurora Australis (approximate location: 66 52 '41'S, $139^{\circ} 41^{\prime} 47^{\prime \prime} \mathrm{E}$ ). Sea-ice pieces were collected with a long handled sieve. Small chunks of approximately $250 \mathrm{ml}$ to $500 \mathrm{ml}$ of bottom ice (distinguished by algal pigment coloration in bottom $1 \mathrm{~cm}$ ) were melted at $2^{\circ} \mathrm{C}$ in $500 \mathrm{ml}$ artificial seawater $(2.2 \% \mathrm{w} / \mathrm{v}$, Sigma $)$ and stored at $2^{\circ} \mathrm{C}$ for two weeks. Upon return to Hobart, aliquots of $200 \mathrm{ml}$ of this liquid were passed through a Nucleopore $0.8 \mu \mathrm{m}$ filters placed over a glass fibre filter (Schleicher \& Schuell), which had been preheated to $450^{\circ} \mathrm{C}$ for one hour. The $0.8 \mu \mathrm{m}$ filter was placed in a glass McCartney bottle containing $10 \mathrm{ml}$ seawater nutrient broth (SNB) described previously (Bowman and Nichols 2002). These enrichment cultures containing media and filters were incubated for $24 \mathrm{hrs}$ at $2^{\circ} \mathrm{C}$, then mixed and $200 \mu \mathrm{l}$ aliquots were removed and spread on SNAgar (SNB with $12 \mathrm{~g} \mathrm{l}^{-1}$ agar added prior to sterilization) and SNAgar + Glucose (2\%w/v). Agar plates were incubated at $4^{\circ} \mathrm{C}$ for four weeks. Additional isolates were obtained from a plankton net $(20 \mu \mathrm{m})$ trawled through the Southern Ocean (approximate location: $\left.65^{\circ} 32^{\prime} 06^{\prime \prime} \mathrm{S}, 143^{\circ} 10^{\prime} 16^{\prime \prime} \mathrm{E}\right)$. Aliquots of $20 \mu \mathrm{l}$ of material from the cod end of the plankton net were spread onto SNAgar and SNAgar + Glucose $(2 \% \mathrm{w} / \mathrm{v})$ and the plates were incubated at $2^{\circ} \mathrm{C}$. 
After initial isolations, both strains were subcultured onto marine agar (MA, $1 \mathrm{~g}$ yeast extract, Oxoid L21; $5 \mathrm{~g}$ bacteriological peptone, Oxoid L37; 32 $\mathrm{g}$ artificial sea salts, Sigma S9883; $15 \mathrm{~g}$ agar; $1000 \mathrm{ml}$ distilled water) and MA supplemented with $3 \%(\mathrm{w} / \mathrm{v})$ glucose $(M A+G l u)$. A glucose solution was prepared and autoclaved separately before being combined with MA. Strains were selected if they displayed a mucoid morphology when grown on MA+Glu

\section{Characterization of bacterial isolates}

\section{$16 S$ rDNA sequence analyses}

The 16S rDNA genes of CAM025 and CAM036 were amplified by PCR according to procedures described by (Bowman et al. 1996) using DNA primers $10 \mathrm{~F}$ and $1519 \mathrm{R}$. The PCR products were purified by Prep-A-Gene purification (Bio-Rad, CA, USA) and the concentration of purified DNA in each sample was measured using a Smart Spec 3000 (Bio-Rad, Regent Park, NSW, Australia). The $16 \mathrm{~S}$ rDNA sequences were obtained with a Beckman Coulter CEQ 2000 automated sequencer for electrophoresis and data collection after preparation according to protocol specified by manufacturer (Beckman Coulter, Inc, Fullerton, CA, USA).

Sequences were manipulated and aligned using BioEdit v. 5.0.9 (Hall 1999). Sequences were compared to $16 S$ rDNA genes available in the GenBank library by BLAST searching (Atschul et al. 1990) through the National Center for Biotechnology Information (U.S. National Institute of Health) Internet site as described by Bowman et al. (1997). Sequences were aligned to their closest related sequences determined from the BLAST searches. PHYLIP (version 3.57c) (Felsenstein 1993) was used to analyse the sequence data and sequence similarities with the maximum likelihood 
algorithm option were determined using DNADIST. Phylogenetic trees were constructed by the neighborliness method with the program NEIGHBOR. The sequence for Escherichia coli (J01695) was included as an outgroup. Partial sequences for these two isolates were deposited into GenBank and assigned the following numbers: AY243365 (CAM025) and AY243366 (CAM036).

\section{Whole-cell fatty acid analyses}

Growth temperatures may affect whole cell fatty acid profiles, therefore similar incubation temperatures to those used in other studies (Bozal et al. 1997, Bowman 1998) were used in this study so that whole cell fatty acid profiles could be compared. Isolates CAM025 and CAM036 were grown on MA at $12^{\circ} \mathrm{C}$ for four weeks. Whole cell fatty acids were extracted from cell material according the MIDI protocol (Sasser 1990). Fatty acid methyl esters (FAME) were treated with N,O-bis-(trimethylsilyl)-trifluoroacetamide to convert hydroxy acids to their corresponding trimethylsilyl (TMSi) ethers for analysis by gas chromatography (GC) and GC-mass spectrometry. Double bond position and geometry of monounsaturated FAME were determined after the formation of dimethyl-disulfide (DMDS) adducts prepared according to methods described previously (Nichols et al. 1986). Determination of the cis and trans geometry in the original monounsaturated FAME was also possible (Skerratt et al. 1991).

GC analyses were performed on a Hewlett Packard 5890A GC fitted with an HP-5 cross-linked methyl silicone fused capillary column (50 m X 0.32 $\mathrm{mm}$ i.d.) and flame ionization detector (FID) and an HP 7673A auto sampler. Helium was the carrier gas. Samples were injected in splitless mode at an oven temperature of $50^{\circ} \mathrm{C}$. After one minute, the oven temperature was raised 
to $150^{\circ} \mathrm{C}$ at $30^{\circ} \mathrm{C} \mathrm{min}{ }^{-1}$ then to $250^{\circ} \mathrm{C}$ at $2^{\circ} \mathrm{C} \mathrm{min}{ }^{-1}$ and finally to $300^{\circ} \mathrm{C}$ at $5^{\circ} \mathrm{C}$ $\min ^{-1}$. GC-MS analysis of the FAME was performed using a Finnigan GCQ Plus GC/MS System fitted with on-column injection set at $45^{\circ} \mathrm{C}$. Samples were injected using an AS2000 auto sampler into a retention gap attached to a HP 5 Ultra 2, $(50 \mathrm{~m} \times 0.32 \mathrm{~mm}$ i.d., and $0.17 \mu \mathrm{m}$ film thickness column using helium for the carrier gas. The chromatograms and mass spectra were manipulated using Excalibur software. Peaks were identified by comparison to known standards, the library included with the software, and by consideration of the mass spectra.

Fatty acids are designated by the total number of carbon atoms:number of double bonds, followed by the position of the double bond from the terminal $(\omega)$ end of the molecule. The suffixes $\mathrm{c}$ and $\mathrm{t}$ indicate cis and trans geometry; the prefixes I and a refer to iso and anteiso branching.

\section{EPS production and characterization analysis}

\section{Growth of CAM025 and CAM036 in batch cultures for EPS production}

A McCartney bottle containing $20 \mathrm{ml}$ Marine broth supplemented with 3 $\%(\mathrm{w} / \mathrm{v})$ glucose $(\mathrm{MB}+\mathrm{Glu})$ was inoculated with approximately ten colonies of either CAM025 or CAM036 from an agar plate $(\mathrm{MA}+\mathrm{Glu})$ inoculated ten days earlier and incubated at $20^{\circ} \mathrm{C}$. This incubation temperature was chosen as it approximates the optimum growth temperature measured for other Pseudoalteromonas strains isolated from the same environment (Bowman 1998). The $20 \mathrm{ml}$ culture was shaken for $24 \mathrm{hr}(200 \mathrm{rpm})$ at $20^{\circ} \mathrm{C}$. This $20 \mathrm{ml}$ culture was used to inoculate $200 \mathrm{ml}$ of the same media and the resulting culture was shaken $(200 \mathrm{rpm})$ and incubated at $20^{\circ} \mathrm{C}$. After $48 \mathrm{hr}$, the purity of 
this culture was checked by subculturing onto a MA+Glu plate and a $10 \mathrm{ml}$ aliquot was removed to measure $\mathrm{pH}$. The remaining broth was used to inoculate $500 \mathrm{ml} \mathrm{MB}+\mathrm{Glu}(\mathrm{pH} 7)$ in a 2 I Schott bottle.

This $500 \mathrm{ml}$ broth culture was bubbled with compressed air $\left(20 \mathrm{lb} \mathrm{in}^{-2}\right)$. Inlet and outlet air was filtered through a $0.2 \mu \mathrm{m}$ Midisart filter (Sartorius Australia Pty. Ltd, VIC). Broth cultures were shaken (150 rpm) at $20^{\circ} \mathrm{C}$ for one week. Purity of this broth was checked by subculturing onto MA+Glu.

The CAM025 isolate was also grown in duplicate $250 \mathrm{ml} \mathrm{MB}+\mathrm{Glu}(\mathrm{pH}$ 8) broth cultures at $-2^{\circ} \mathrm{C}, 10^{\circ} \mathrm{C}$ and $20^{\circ} \mathrm{C}$. The baffled flasks were incubated in oscillating water baths (Ratek Pty Ltd, Australia) fitted with refrigeration units, which cooled and circulated antifreeze liquid at the desired temperature. The batch cultures at $-2^{\circ} \mathrm{C}, 10^{\circ} \mathrm{C}$ were harvested after 2 weeks incubation. The cultures at $20^{\circ} \mathrm{C}$ were harvested after 1 week. The final $\mathrm{pH}$ was measured for each culture at time of harvest.

\section{Isolation and purification of CAM025 and CAM036 EPS}

Culture broth was centrifuged at $30000 \mathrm{~g}$ for $2 \mathrm{hr}$ at $4^{\circ} \mathrm{C}$. The cell pellets were freeze-dried and weighed. The supernatants were pressure filtered successively through cellulose nitrate filters with the following pore sizes: $8.0 \mu \mathrm{m}, 3.0 \mu \mathrm{m}, 1.2 \mu \mathrm{m}, 0.8 \mu \mathrm{m}$ and $0.45 \mu \mathrm{m}$ (Sartorius Australia Pty. Ltd., VIC). EPS were precipitated from the final filtrate after the addition of cold ethanol (filtrate $60 \mathrm{ml}$ / ethanol $40 \mathrm{ml}$ ) and the solution was chilled to $2^{\circ} \mathrm{C}$ over night. The resulting precipitate was recovered by vacuum filtration through scintered glass. An additional $100 \mathrm{ml}$ cold ethanol was added to the filtrate and the solution was placed at $-20^{\circ} \mathrm{C}$ overnight. The precipitate was recovered as above. The precipitates were washed with $70 \%$ to $100 \%$ ethanol 
- water mixtures. After washing with ethanol, the EPS were combined and dried in a desiccator and stored at room temperature. To remove excess salts, the EPS were redissolved in distilled water and dialyzed (molecular weight cut off of 100,000 daltons, Spectra/Por, Spectrum Laboratories, CA, USA) against distilled water for 2 days at room temperature (approx $25^{\circ} \mathrm{C}$ ). Excess water was removed under vacuum before lyophilization. The EPS were stored at room temperature until analysis.

\section{EPS Characterization}

\section{Colorimetric Analyses}

Uronic acid content of the EPS was determined by the metahydroxydiphenyl method (Blumenkrantz and Asboe-Hansen 1973, FilisettiCozzi and Carpita 1991). Protein content was determined by the Lowry protein assay (Lowry et al. 1951) with bovine serum albumin as the standard. The total neutral carbohydrate content was determined by the orcinol-sulfuric acid method modified by Rimington (1931).

\section{Monosaccharide analyses}

To a solution containing $250 \mu \mathrm{g}$ total EPS, $50 \mu \mathrm{g}$ erythritol was added as an internal standard. Samples for GC analysis were prepared in triplicate. The polymer was hydrolysed by the addition of methanolic $\mathrm{HCl}(3 \mathrm{~N}$, Supelco, PA, USA) and heating for $16 \mathrm{hr}$ at $80^{\circ} \mathrm{C}$ (Kamerling et al. 1975, modified by Montreuil et al. 1986). The monosaccharides were converted to their trimethylsilyl derivatives by the addition of Bis(trimethylsilyl)trifluoroacetamide:trimethylchlorosilane / 99:1 (Supelco, PA, USA) and pyridine followed by incubation at room temperature for $2 \mathrm{hr}$. The 
samples were then dried under nitrogen and redissolved in dichloromethane prior to analysis.

\section{Gas Chromatography}

Analyses of the monosaccharides as trimethylsilyl derivatives were performed on a GC8000 (Fisons, France) gas chromatograph (GC) fitted with an automatic injector, a flame ionization detector (FID) and a CP-Sil-5CB glass capillary column ( 0.32 mm X 60 m, Chrompac, Varian, France). Hydrogen was the carrier gas. The GC oven was temperature programmed as follows: $50^{\circ} \mathrm{C}$ for $1 \mathrm{~min}$ then an increase of $20^{\circ} \mathrm{C} / \mathrm{min}$ until $120^{\circ} \mathrm{C}$, followed by a gradient of $2^{\circ} \mathrm{C} / \mathrm{min}$ until $240^{\circ} \mathrm{C}$.

\section{FT-IR Spectroscopy}

Pellets for infrared analysis were obtained by grinding a mixture of 2 mg polysaccharide with $200 \mathrm{mg}$ dry $\mathrm{KBr}$, followed by pressing the mixture into a $16 \mathrm{~mm}$ diameter mold. The Fourier transform-infrared (FT-IR) spectra were recorded on a Bruker Vector 22 instrument with a resolution of $4 \mathrm{~cm}^{-1}$ in the $4000-400 \mathrm{~cm}^{-1}$ region. Sulfate content was determined by FT-IR spectroscopy according to the method of Lijour et al. (1994).

\section{NMR Spectroscopy}

NMR spectra were obtained on a Bruker AMX-500 $\left(500 \mathrm{MHz}\right.$ for ${ }^{1} \mathrm{H}$ and $125 \mathrm{MHz}$ for ${ }^{13} \mathrm{C}$ ) at $55^{\circ} \mathrm{C}$. Samples were exchanged three times with $\mathrm{D}_{2} \mathrm{O}$ with intermediate lyophilization and finally dissolved in $500 \mu \mathrm{D}_{2} 0$ to a final concentration close to $30 \mathrm{mg}$. Chemicals shifts were reported in parts per million relative to sodium $2,2,3,3-\mathrm{d}_{4}$-(trimethylsilyl) propanoate for ${ }^{1} \mathrm{H}$ and CDCl3 for ${ }^{13} \mathrm{C}$ NMR spectra. 


\section{RESULTS}

\section{Isolation and characterization of bacterial isolates}

\section{Cultivation of isolates}

Bacterial strain CAM025 was isolated from filtered sea-ice particulates, while CAM036 was isolated from diatom-rich trawled material. Both strains showed enhanced growth on MA+Glu and, after 14 days of growth at $20^{\circ} \mathrm{C}$ on this medium, produced opaque, circular, convex or pulvinate, off-white colonies 1-2 mm in diameter with a mucoid texture and an entire margin. Both were Gram-negative curved rods $(2-5 \mu \mathrm{m} \times 0.5 \mu \mathrm{m})$.

\section{Whole cell fatty acid analyses}

Table 1 contains a list of the whole cell fatty acids present in CAM025 and CAM 036 as the percentage of the total fatty acids. Major whole cell fatty acids in CAM025, in decreasing order of abundance, included 17:1 $108 \mathrm{c}$,

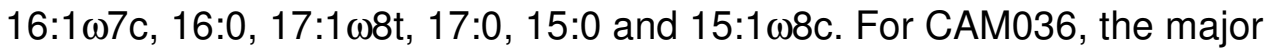
whole cell fatty acids included 16:1 $17 \mathrm{c}, 17: 1 \omega 8 \mathrm{c}, 16: 0,16: 1 \omega 7 \mathrm{t}, \beta \mathrm{OH}-12: 0$,

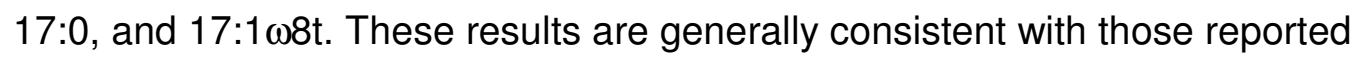
for Pseudoalteromonas strains from other studies (Bozal et al. 1997, Bowman 1998.

\section{$16 S$ rDNA sequences}

Analysis of partial 16S rDNA sequences from CAM025 (1488 base pairs) and CAM036 (1485 base pairs) also indicated that both isolates belonged to the genus Pseudoalteromonas, with the closest species $P$. haloplanktis (sequence similarity CAM025: 99.3\%, CAM036: 99.4\%) and $P$. 
nigrifaciens (sequence similarity CAM025: 99.6\%, CAM036: 99.8\%). Figure 1 shows the phylogenetic relationship of Pseudoalteromonas species and two Antarctic isolates (CAM025 and CAM036) based on 16S rDNA sequences. The tree was created using maximum-likelihood distanced clustered by the neighbor-joining method (Bar: 0.1 changes per mean nucleotide position). Numbers in parentheses are GenBank nucleotide accession numbers. Outgroup for the analysis was Escherichia coli (J01695). Precise species identification of CAM025 and CAM036 will require further investigation by DNA-DNA hybridization.

\section{Characterization of exopolysaccharides}

\section{Colorimetric analyses}

The gross chemical composition of bacterial EPS is presented in Table 2. Protein content for EPS from CAM025 and CAM036 was low (2-3\%). Neutral sugars dominated in both EPS and accounted for $74 \%$ and $50 \%$ of EPS from CAM025 and CAM036, respectively. Both EPS contained significant amounts of uronic acids (CAM025 - 22\%; CAM036-25\%) according to colorimetric analyses.

\section{FT-IR analyses}

FT-IR spectra of the CAM025 and CAM036 EPS (Figure 2) displayed a broad $\mathrm{O}-\mathrm{H}$ stretching band above $3000 \mathrm{~cm}^{-1}$ and intense absorptions between 1650 and $1050 \mathrm{~cm}^{-1}$ characteristic of polysaccharides. An absorbance at approximately $1730 \mathrm{~cm}^{-1}$ indicated the presence of carboxyl groups (Lijour et al. 1994). In addition, a small absorption at $1550 \mathrm{~cm}^{-1}$, indicative of either amino sugars or proteins was present in CAM036 EPS, but extremely small in 
CAM025 EPS. GC data confirmed the presence of amino sugars in the CAM036 EPS (Table 3) and minor amounts in the CAM025 EPS. Sulfate content in each EPS, determined by the presence of a doublet at 1230-1250 $\mathrm{cm}-1$, was calculated to be $5 \%$ for each of the EPS samples (Table 2).

\section{Monosaccharides analyses}

Molar ratios of monosaccharides are listed in Table 3. The EPS secreted by the bacterial strain CAM025 was composed of five major monosaccharides with glucose predominating over other neutral sugars (arabinose, galactose and rhamnose). Traces of ribose, fucose and mannose were also present. The presence of galacturonic acid was also substantial, accounting for approximately one-quarter of the monosaccharides in the EPS. The EPS produced by bacterial isolate CAM036 was composed of five monosaccharides with galacturonic acid predominating over the other sugars accounting for one third of the monosaccharides present. Mannose and glucose were the most abundant neutral sugars along with arabinose while galactose was present as traces. $\mathrm{N}$-acetyl galactosamine was a relatively abundant aminyl-sugar in this EPS.

\section{NMR Spectra}

From the ${ }^{1} \mathrm{H}$ and ${ }^{13} \mathrm{C}$ NMR spectra of the native EPS, it is possible to extrapolate some information. The ${ }^{1} \mathrm{H}$ spectrum showed essentially five and seven anomeric signals for the EPS produced by isolates CAM025 and CAM036 respectively. The presence in both EPS of acetyl groups linked to different sugars was confirmed by a signal at $\delta 2.02 \mathrm{ppm}$. Interestingly, the signals at $\delta 2.55 \mathrm{ppm}$ and $\delta 2.68 \mathrm{ppm}$, indicative of a succinyl group, were 
present only for the EPS produced by isolate CAM036. The ${ }^{1} \mathrm{H}$ NMR spectra for the EPS from CAM036 are presented in Figure 3.

\section{EPS yield determinations for CAM025}

The average change in $\mathrm{pH}$ over the period of incubation of two CAM025 cultures at each of the three temperatures was calculated. After two weeks at $-2^{\circ} \mathrm{C}$ and $10^{\circ} \mathrm{C}$, the average decrease of 0.63 and $0.93 \mathrm{pH}$ units respectively, was observed. After one week at $20^{\circ} \mathrm{C}$, the average decrease in $\mathrm{pH}$ for these two cultures was $1.69 \mathrm{pH}$ units. The final yields of EPS for CAM025 incubated at $-2^{\circ} \mathrm{C}, 10^{\circ} \mathrm{C}$ and $20^{\circ} \mathrm{C}$ (Figure 4) were calculated by dividing the final weight of the freeze-dried polymer for each culture by the weight of the corresponding freeze-dried cell pellets. Results show that the yield of EPS for CAM025 grown at $-2^{\circ} \mathrm{C}$ and at $10^{\circ} \mathrm{C}$ was approximately 100 mg EPS per gram dry weight of cells. The yield of EPS for the same strain grown at $20^{\circ} \mathrm{C}$ was approximately thirty fold lower.

\section{DISCUSSION}

The bacterial strain CAM025 was obtained from particles from melted Antarctic sea ice retained on a filter with a pore size of $0.8 \mu \mathrm{m}$. CAM036 was isolated from particles captured by a plankton net $(20 \mu \mathrm{m})$ towed through the Southern Ocean. Both psychrotolerant strains (growth at $4^{\circ} \mathrm{C}$ and $25^{\circ} \mathrm{C}$ ) displayed an enhanced mucoid morphology on marine agar supplemented with glucose. Results from 16S rDNA sequencing and whole cell fatty acid analyses indicate that these two isolates were closely related and belonged to the genus Pseudoalteromonas. 
Previous studies have shown that many Pseudoalteromonas strains are the psychrotrophic bacteria with a temperature growth range from $4^{\circ} \mathrm{C}$ to $30^{\circ} \mathrm{C}$ (Bozal et al. 1997, Bowman 1998), and show optimal growth at $22^{\circ} \mathrm{C}$ to $25^{\circ} \mathrm{C}$ (Bowman 1998). Members of this genus are the bacteria most frequently isolated from sea ice and underlying sea water (Bowman et al. 1997, Bowman 1998;Delille 1992). In liquid culture amended with glucose, CAM025 and CAM036 produced EPS, which when chemically analysed by colorimetric techniques were shown to have similarly low amounts of protein and abundant neutral sugars and uronic acids. FT-IR and NMR analyses confirmed the presence of acetyl groups and low amounts of ester sulfate groups in both polysaccharides. Similar biochemical compositions were observed in previous studies of EPS from Alteromonas species isolated from hydrothermal vent communities (Rougeaux et al. 1996, Cambon-Bonavita et al. 2002, Raguénès et al. 2003).

Arctic studies (Krembs and Engel 2001, Krembs et al. 2002) have shown that large quantities of microbially produced EPS occur in sea ice and at the ice-water interface. This material was positively correlated to bacterial abundances although diatoms were thought to dominate the EPS production in this system. These authors suggest high concentrations of EPS in the brine channels may provide buffering against harsh winter conditions and high salinity as well as cryoprotect the microbes living there against ice crystal formation. In our study, the EPS yield data suggest that there is a decreased production of EPS at higher temperature $\left(20^{\circ} \mathrm{C}\right)$ for the Antarctic sea ice strain tested. This finding supports the proposed hypothesis that EPS 
production by psychrotolerant bacteria may play an important role in the sea ice microbial community.

The Arctic sea ice studies (Krembs and Engel 2001, Krembs et al. 2002) also demonstrated that the neutrally buoyant polymeric material was carried large distances by prevailing under-ice currents and ice drifts. Studies in more temperate waters show marine bacterial EPS production plays a major role in the aggregate formation process (Biddanda 1986, Decho 1990). When released into the water column, a combination of biological, chemical and physical forces causes this colloidal material to form aggregates (Alldredge and Jackson 1995, Passow 2000, Kiorboe 2001), which become centers of high microbiological heterotrophic activity (Kiorboe 2001).

Preliminary characterizations show that the structure of the EPS from CAM025 and CAM036 includes sulfate as well as high levels of uronic acids as galacturonic acid, along with acetyl groups. In addition, the EPS from CAM036 was shown by NMR data to include a succinyl group. These features convey an overall polyanionic or 'sticky' quality to the EPS in the marine environment, since at the $\mathrm{pH}$ of seawater $(\mathrm{pH} \mathrm{8.0)}$ many of the acidic groups present on these polymers are ionized (Decho 1990). This 'stickiness' is important in terms of the affinity of these EPS for binding to other cations such as dissolved metals (Brown and Lester 1982).

The EPS were subjected to further analytical characterization and based on relative molar ratios of monosaccharides (normalized to arabinose), there were several similarities between these two EPS including the presence of the sole acidic sugar, galacturonic acid in significant proportion. Glucose was a major neutral sugar present in both polysaccharides, albeit to varying 
degrees. There were also several differences between the EPS from the two Antarctic strains. Rhamnose and fucose were present in the CAM025 EPS and absent in CAM036 EPS. Mannose accounted for a large proportion in the CAM036 EPS while being present at low levels in the EPS produced by CAM025, based on molar ratios. Another significant difference is the presence of aminyl sugars in only one polysaccharide (CAM036) as determined by both the GC and NMR analyses.

In this study we have demonstrated that two Antarctic marine bacterial isolates; one from Southern Ocean particulate material and the other from melted sea ice, belong to the genus Pseudoalteromonas and produce different EPS in laboratory culture. This feature is also found in bacteria from deep-sea hydrothermal vents (Rougeaux et al. 1996, Raguénès et al. 1997) and other aquatic microbial communities (Nicolaus et al. 1999). The EPS produced by Antarctic bacterial isolates examined in this study appear to be polyanionic and, therefore, 'sticky' with respect to cations such as trace metals. The availability of iron as a trace metal is of critical importance in the Southern Ocean where it is know to limit primary production (Scharek et al. 1997). Since $99 \%$ of dissolved iron in the ocean is bound to organic ligands (Wu et al. 2001), implications for the role of these bacterial polysaccharides in the Antarctic marine environment require further investigation.

Biotechnological uses for microbially produced EPS include environmental, clinical, nutritional and cosmetic applications, to name a few (Guezennec 2000, Gutnick and Bach 2000, Sutherland 2001). Increased knowledge of the role of Antarctic bacterial EPS will also provide insight into possible commercial uses for these novel polymers. 


\section{ACKNOWLEDGEMENTS}

The authors thank Jenny Skerratt and Andrew Pankowski for sample

collection. Andrew Bisset and Guy Abell from the School of Agricultural

Science at the University of Tasmania are acknowledged for assistance in the molecular laboratory. John Gibson and Peter Nichols from CSIRO Marine Research, Hobart provided assistance with fatty acid analyses and comment on the draft manuscript. The authors are grateful to Nelly Kervarec from the University of Western Brittany for technical support in NMR analysis. We also acknowledge the efforts of two anonymous reviewers whose comments strengthened this manuscript. CMN was supported by an Australian Postgraduate Award and an Australian Antarctic Science Scholarship. CMN also received a travel award from the Australian Academy of Science and the French Embassy in Canberra, Australia.

\section{REFERENCES}

Alldredge A (2000) Interstitial dissolved organic carbon (DOC) concentrations within sinking marine aggregates and their potential contribution to carbon flux. Limnol Oceanogr 45: 1245-1253

Alldredge A, Jackson GA (1995) Aggregation in marine systems. Deep-Sea Research II 42: 1-7

Atschul SF, Gish W, Miller W, Myers EW, Lipman EJ (1990) Basic local alignment search tool. J Microbiol Biotechn 215: 403-410

Biddanda BA (1986) Structure and function of microbial aggregates. Oceanol Acta 9: 209-211

Biddanda BA (1988) Microbial aggregation and degradation of phytoplanktonderived detritus in seawater. II. Microbial metabolism. Marine EcologyProgress Series 42: 89-95

Blumenkrantz N, Asboe-Hansen G (1973) New method for quantitative determination of uronic acids. Anal Biochem 54: 484-489 
Bowman JP (1998) Pseudoalteromonas prydzensis sp. nov., a psychrotrophic, halotolerant bacterium from Antarctic sea ice. Int J Syst Bacteriol 48: 1037-1041

Bowman JP, Cavanagh J, Austin JJ, Sanderson K (1996) Novel Psychrobacter species from Antarctic ornithogenic soils. Int J Syst Bacteriol 46: 841-848

Bowman JP, McCammon SA, Brown MV, Nichols DS, McMeekin TA (1997) Diversity and association of psychrophilic bacteria in Antarctic sea ice. Appl Environ Microbiol 63: 3068-3078

Bowman JP, Nichols DS (2002) Aequorivita gen. nov., a member of the family Flavobacteriaceae isolated from terrestrial and marine Antarctic habitats. Int $\mathrm{J}$ Syst Evol Micro 52: 1533-1541

Bozal N, Tudela E, Rossello-Mora R, Lalucat J, Guinea J (1997) Pseudoalteromonas antarctica sp. nov., isolated from an Antarctic coastal environment. Int J Syst Bacteriol 47: 345-351

Brown MJ, Lester JN (1982) Role of bacterial extracellular polymers in metal uptake in pure bacterial culture and activated sludge - I. Water Res 16: 15391548

Cambon-Bonavita M-A, Raguénès G, Jean J, Vincent $P$, Guézennec J (2002) A novel polymer produced by a bacterium isolated from a deep-sea hydrothermal vent polychaete annelid. J Appl Microbiol 93: 310-315

Costerton JW (1999) The role of bacterial exopolysaccharides in nature and disease (Reprinted from Developments in Industrial Microbiology, vol 26, pp 249-261, 1985). J Ind Microbiol Biot 22: 551-563

Decho AW (1990) Microbial exopolymer secretions in ocean environments: their role(s) in food webs and marine processes. In: Barnes M (ed) Oceanogr Mar Biol Annu Rev. Aberdeen Univ Press, Aberdeen, pp 73-153

Delille D (1992) Marine bacterioplankton at the Weddell sea ice edge, distribution of psychrophilic and psychrotrophic populations. Polar Biol 12: 205-210

Felsenstein J (1993) PHYLIP (phylogeny inference package), version 3.57c. University of Washington, Seattle, Washington

Filisetti-Cozzi TMCC, Carpita NC (1991) Measurement of uronic acid without interference of neutral sugars. Anal Biochem 197: 157-162

Fowler SW, Knauer GA (1986) Role of large particles in the transport of elements and organic compounds through the oceanic water column. Prog Oceanogr 16: 147-194 
Gleitz M, Thomas DN (1993) Variation in phytoplankton standing stock, chemical composition and physiology during sea-ice formation in the southeastern Weddell Sea. J Exp Mar Biol Ecol 173: 211-230

Grossmann S, Dieckmann GS (1994) Bacterial standing stock, activity and carbon production during formation and growth of sea ice in the Weddell Sea. Appl Environ Microbiol 60: 2746-2753

Guezennec J (2000) The deep-sea hydrothermal vents: a new source of bacterial exopolysaccharides of biotechnological interest? Polymerix 2000, Rennes, France, pp 187-193

Guezennec JG, Pignet P, Raguénès G, Deslandes E, Lijour Y, Gentric E (1994) Preliminary chemical characterization of unusual eubacterial exopolysaccharides of deep-sea origin. Carbohydrate Polymers 24: 287-294

Gutnick DL, Bach H (2000) Engineering bacterial biopolymers for the biosorption of heavy metals; new products and novel formulations. Appl Microbiol Biotechnol 54: 451-460

Hall TA (1999) BioEdit: a user-friendly biological sequence alignment editor and analysis program for Windows 95/98/NT. Nucl Acids Symp Ser 41: 95-98

Helmke $E$, Weyland $H$ (1995) Bacteria in the sea ice and underlying water on the eastern Weddell Sea in midwinter. Mar Ecol-Prog Ser 117: 269-287

Kamerling JP, Gerwig GJ, Vliegenthart JFG, Clamp JR (1975)

Characterization by gas-liquid chromatography-mass spectrometry and proton-magnetic-resonance spectroscopy of pertrimethylsilyl methyl glycosides obtained in the methanolysis of glycoproteins and glycopeptides. Biochem J 151: 491-495

Kiorboe T (2001) Formation and fate of marine snow: small-scale processes with large scale implications. Sci Mar 65: 57-71

Krembs C, Eicken H, Junge K, Deming JW (2002) High concentrations of exopolymeric substances in Arctic winter sea ice: implications for the polar ocean carbon cycle and cryoprotection of diatoms. Deep-Sea Res Pt I 49: 2163-2181

Krembs C, Engel A (2001) Abundance and variability of microorganisms and transparent exopolymer particles across ice-water interface of melting firstyear sea ice in the Laptev Sea (Arctic). Mar Biol 138: 173-185

Lijour Y, Gentric E, Deslandes E, Guézennec J (1994) Estimation of the sulfate content of hydrothermal vent bacterial polysaccharides by Fourier Transform Infrared Spectroscopy. Anal Biochem 220: 244-248

Lowry OH, Rosebrough NJ, Farr AL, Randall RJ (1951) Protein measurement with the Folin-phenol reagent. J Biol Chem 193: 265-274 
Montreuil J, Bouquelet S, Debray H, Fournet B, Spik G, Strecker G (1986) Glycoproteins. In: Chaplin MF, Kennedy JF (eds) Carbohydrate analysis, a practical approach. IRL Press, Oxford, pp 143-204

Nichols PD, Guckert JB, White DC (1986) Determination of monounsaturated fatty acid double-bond position and geometry for microbial monocultures and complex consortia by capillary GC-MS of their dimethyl disulfide adducts. J Microbiol Meth 5: 49-55

Nicolaus B, Lama L, Esposito E, Manca MC, Improta R, Bellitti MR, Duckworth AW, Grant WD, Gambacorta A (1999) Haloarcula spp. able to biosynthesize exo- and endopolymers. J Indus Microbiol Biot 23: 489-496

Passow U (2000) Formation of transparent exopolymer particles, TEP, from dissolved precursor material. Mar Ecol-Prog Ser 192: 1-11

Passow U, Alldredge A (1994) Distribution, size and bacterial colonization of transparent exopolymer particles (TEP) in the ocean. Mar Ecol-Prog Ser 113: 185-198

Raguénès G, Cambon-Bonavita MA, Lohier JF, Boisset C, Guézennec J (2003) A novel, highly viscous polysaccharide excreted by an Alteromonas isolated from a deep-sea hydrothermal vent shrimp. Curr Microbiol 46: 448452

Raguénès $\mathrm{GHC}$, Peres $A$, Ruimy $R$, Pignet $P$, Christen $R$, Loaec $M$, Rougeaux H, Barbier G, Guézennec JG (1997) Alteromonas infernus sp. nov., a new polysaccharide-producing bacterium isolated from a deep-sea hydrothermal vent. J Appl Microbiol 82: 422-430

Rath J, Wu K, Herndl G, Delong E (1998) High phylogenetic diversity in a marine-snow- associated bacterial assemblage. Aquatic Microbial Ecology 14: 261-269

Rimington C (1931) The carbohydrate complex of the serum proteins. II : Improved method for isolation and redetermination of structure, isolation of glucosaminodimannose from proteins of ox blood. Biochem J 25: 1062-1071

Rougeaux H, Pichon R, Kervarec N, Raguénès GHC, Guézennec JG (1996) Novel bacterial exopolysaccharides from deep-sea hydrothermal vents. Carbohydr Polym 31: 237-242

Sasser M (1990) Identification of bacteria by gas chromatography of cellular fatty acids. Microbial ID, 101, Newark, DE, USA

Scharek R, Vanleeuwe MA, Debaar HJW (1997) Responses of southern ocean phytoplankton to the addition of trace metals. Deep-Sea Res Pt II 44: 209-227

Skerratt JH, Nichols PD, Mancuso CA, James SR, Dobson SJ, McMeekin TA, Burton $\mathrm{H}$ (1991) The phospholipid ester-linked fatty acid composition of 
members of the family Halomonadaceae and the genus Flavobacterium: a chemotaxonomic guide. Syst Appl Microbiol 14: 8-13

Smith DC, Simon M, Alldredge A, Azam F (1992) Intense hydrolytic enzyme activity on marine aggregates and implications for rapid particle dissolution. Nature 359: 139-141

Sullivan CW, Palmisano AC (1984) Sea ice microbial communities: distribution, abundance and diversity of ice bacteria in McMurdo Sound, Antarctica, in 1980. Appl Environ Microbiol 47: 788-795

Sutherland IW (2001) Biofilm exopolysaccharides: a strong and sticky framework. Microbiology-(UK) 147: 3-9

White DC (1986) Quantitative physiochemical characterization of bacterial habitats. In: Poindexter JS, Leadbetter ER (eds) Methods and Special Applications in Bacterial Ecology. Plenum Press, New York, pp 177-203

Wu JF, Boyle E, Sunda W, Wen LS (2001) Soluble and colloidal iron in the oligotrophic North Atlantic and North Pacific. Science 293: 847-849 


\section{FIGURE LEGENDS}

\section{Figure 1}

Phylogenetic relationship of Pseudoalteromonas species and two Antarctic isolates (CAM025 and CAM036) based on 16S rDNA sequences. The tree was created using maximum-likelihood distanced clustered by the neighborjoining method. Bar 0.1 changes per mean nucleotide position. Numbers in parentheses are GenBank nucleotide accession numbers. Outgroup for the analysis was Escherichia coli (J01695).

\section{Figure 2}

FT-IR spectra of EPS from CAM025 and CAM036, two Antarctic marine bacteria grown in laboratory culture. Absorbances at $3000-3600 \mathrm{~cm}^{-1}$ are indicative of $\mathrm{OH}$ stretch; $1730 \mathrm{~cm}^{-1}$, carboxyl groups; $1650 \mathrm{~cm}^{-1}$ and $1050 \mathrm{~cm}^{-}$

${ }^{1}$, polysaccharides; $1550 \mathrm{~cm}^{-1}$, amino sugars and/or proteins; $1230-1250 \mathrm{~cm}^{-1}$, sulfate.

\section{Figure 3}

${ }^{1} \mathrm{H}$ NMR spectra of EPS produced in laboratory culture by Antarctic marine bacterialisolate, CAM036. Signal at $\delta 2.02 \mathrm{ppm}$ indicates acetyl group, the signals at $\delta 2.55 \mathrm{ppm}$ and $\delta 2.68 \mathrm{ppm}$, indicate a succinyl group.

\section{Figure 4}

Yield of EPS (mg EPS per g dry weight of cells) from batch cultures CAM025 incubated at $-2^{\circ} \mathrm{C}, 10^{\circ} \mathrm{C}$ and $20^{\circ} \mathrm{C}$. 


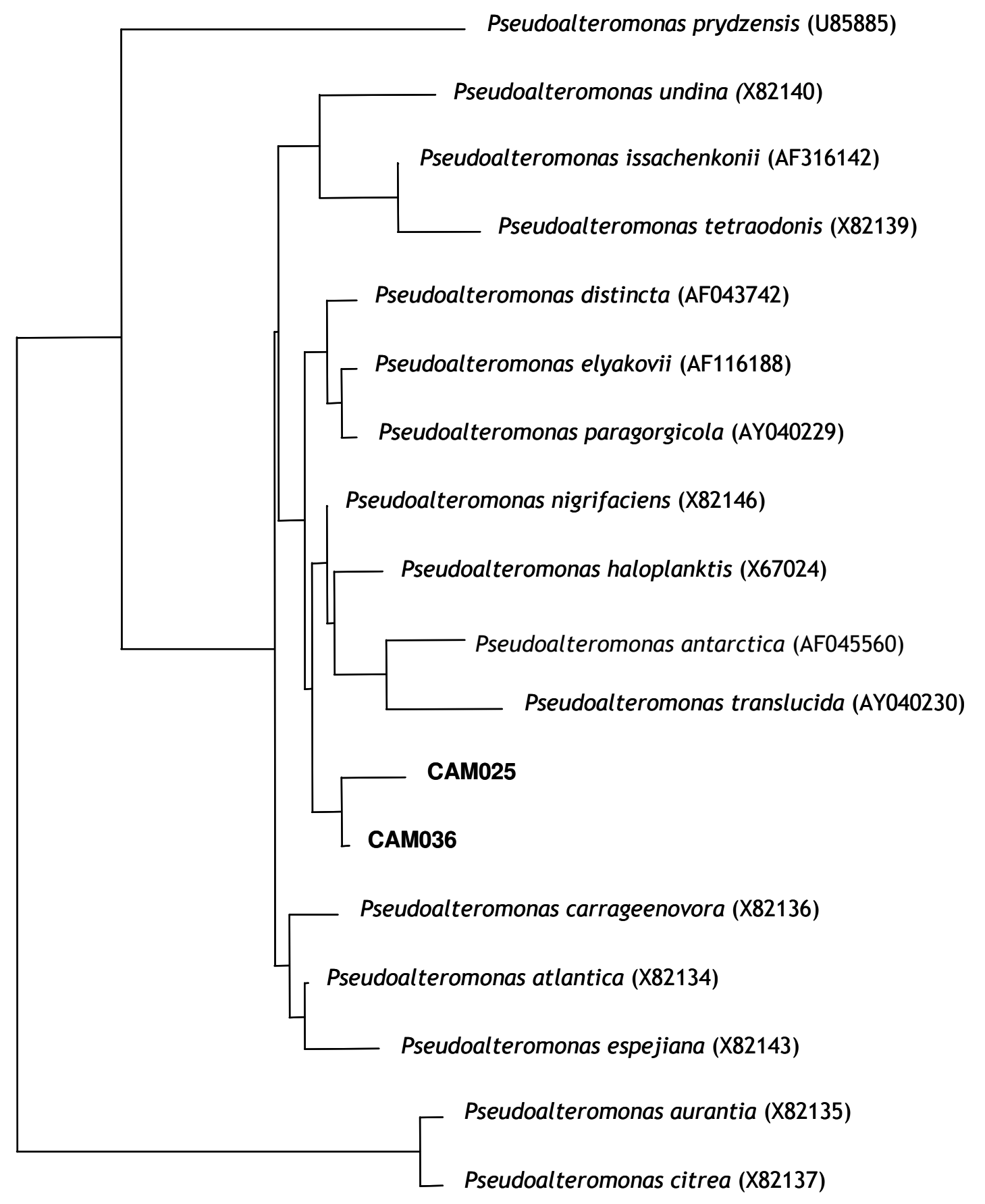

Figure 1 


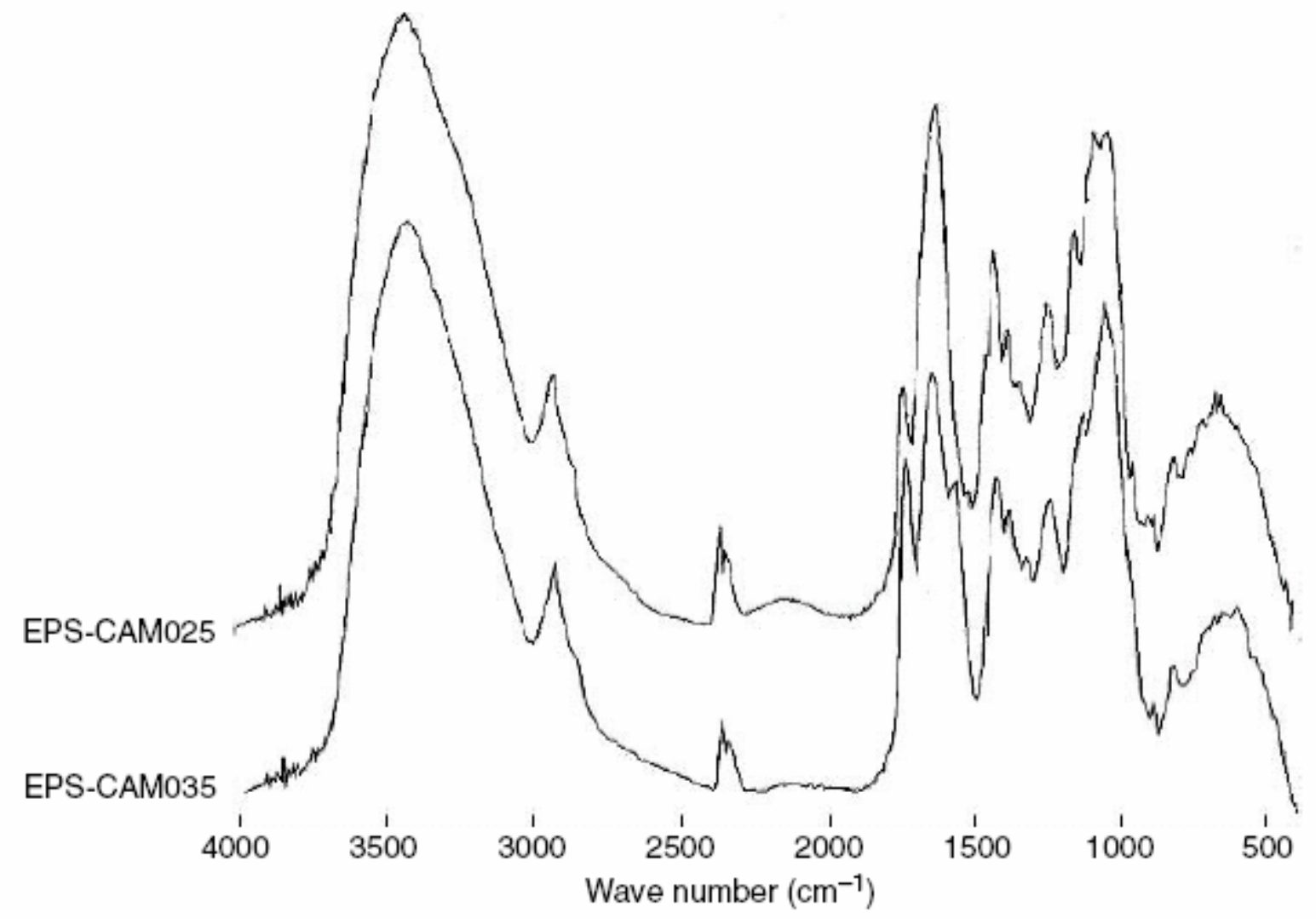

Figure 2

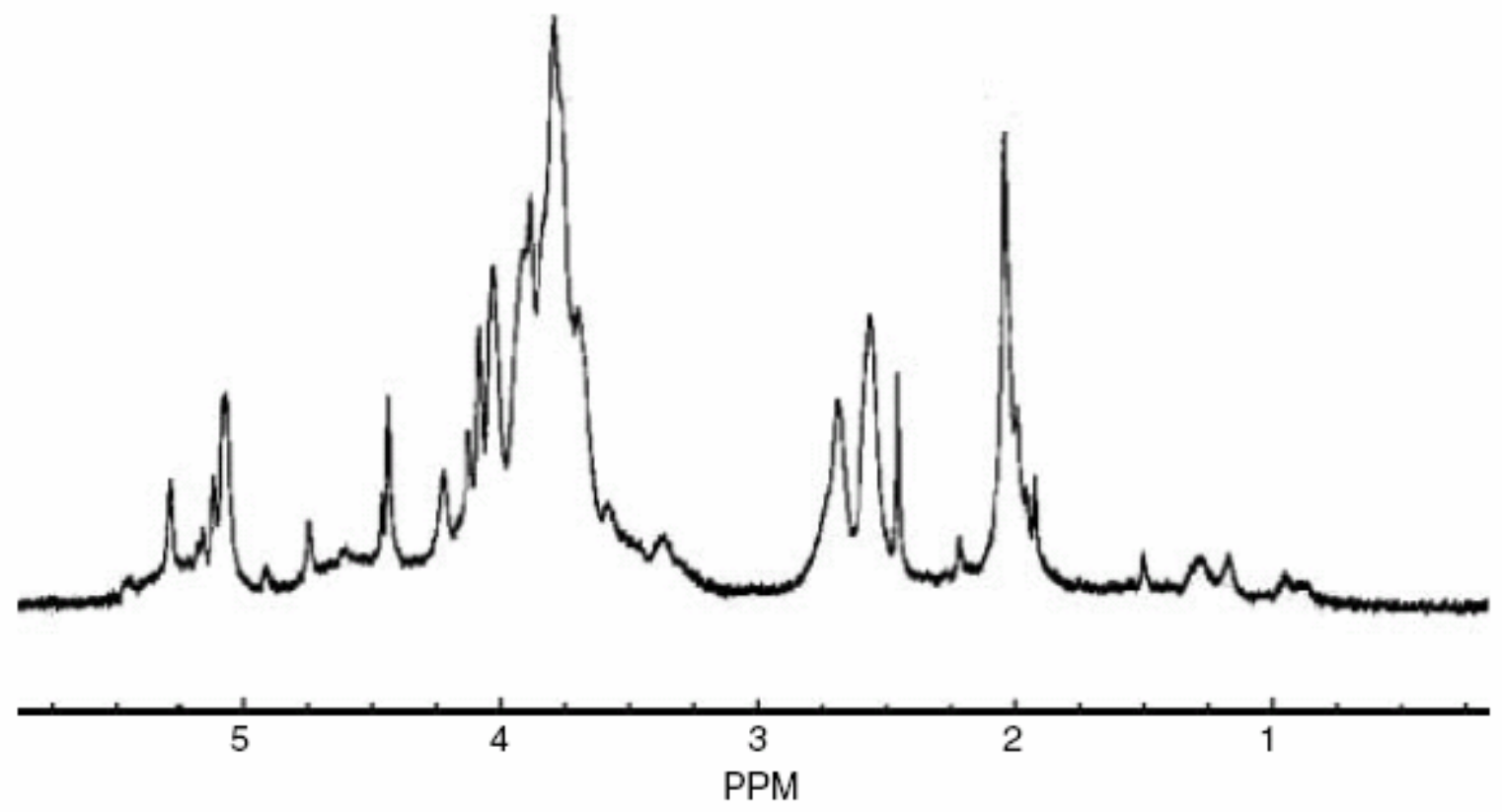

Figure 3 


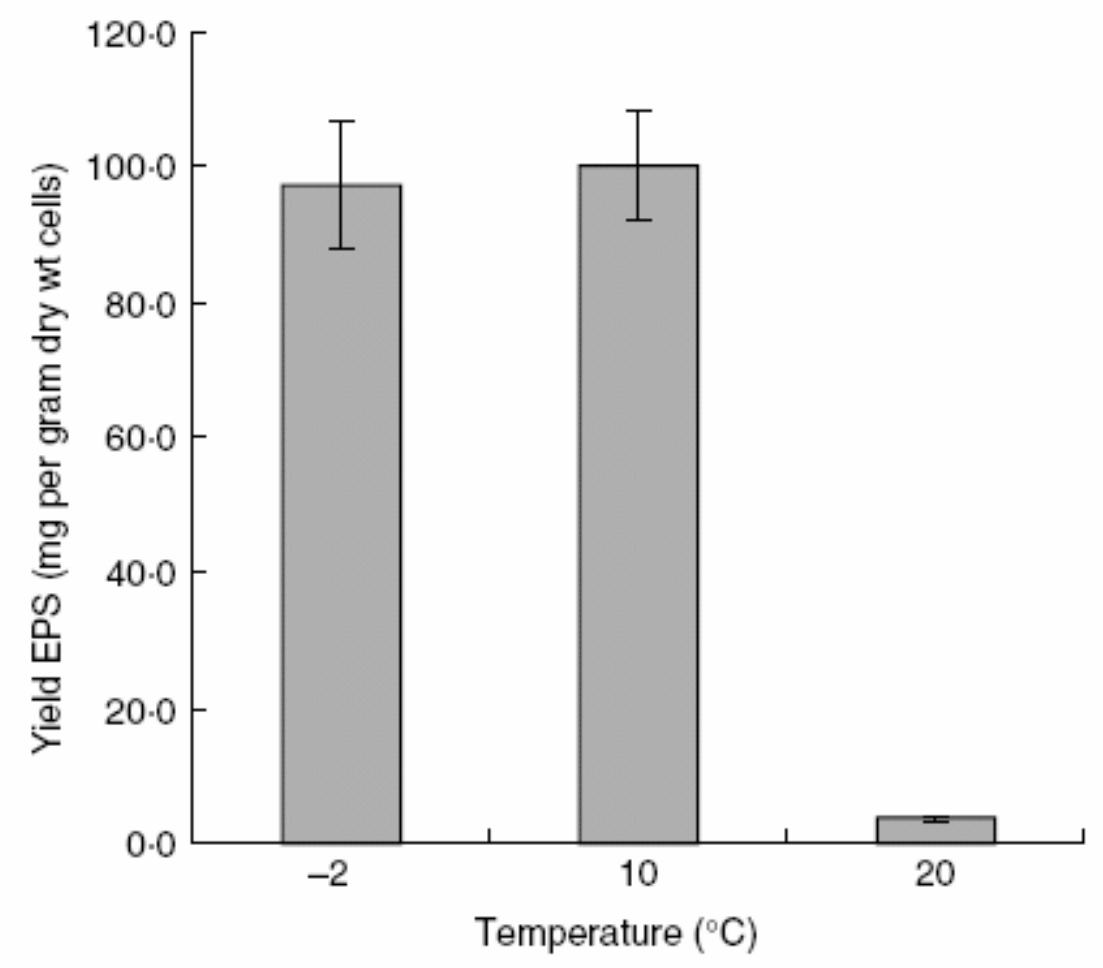

Figure 4

Table 1 Whole-cell fatty acids of two Antarctic marine bacterial isolates* reported as per cent of total area

\begin{tabular}{|c|c|c|}
\hline Fatty acid & CAM025 & CAM036 \\
\hline $\mathrm{i} 14: 0+\beta-\mathrm{OH} 12: 0$ & $1 \cdot 5$ & $2 \cdot 3$ \\
\hline $14: 0$ & $\operatorname{tr}$ & $\operatorname{tr}$ \\
\hline$\beta-\mathrm{OH} 12: 0$ & $3 \cdot 5$ & $6 \cdot 5$ \\
\hline i15:1 & 1.9 & $2 \cdot 1$ \\
\hline $15: 1 \omega 8 \mathrm{c}$ & $4 \cdot 0$ & $3 \cdot 3$ \\
\hline $15: 1 \omega 8 \mathrm{t}$ & 1.5 & $1 \cdot 8$ \\
\hline $15: 0$ & $4 \cdot 7$ & $3 \cdot 3$ \\
\hline$\beta$-OH 13:0 & $2 \cdot 2$ & $3 \cdot 3$ \\
\hline i16:0 & $\operatorname{tr}$ & $\operatorname{tr}$ \\
\hline $16: 1 \omega 9 \mathrm{c}$ & $\operatorname{tr}$ & $\operatorname{tr}$ \\
\hline $16: 1 \omega 7 \mathrm{c}$ & $21 \cdot 4$ & $26 \cdot 2$ \\
\hline $16: 1 \omega 7 \mathrm{t}$ & $7 \cdot 5$ & 6.7 \\
\hline $16: 0$ & $7 \cdot 5$ & $7 \cdot 3$ \\
\hline $17: 1 \omega 8 \mathrm{c}$ & $29 \cdot 3$ & $24 \cdot 2$ \\
\hline $17: 1 \omega 8 \mathrm{t}$ & $6 \cdot 8$ & $4 \cdot 1$ \\
\hline $17: 0$ & $4 \cdot 8$ & $5 \cdot 6$ \\
\hline $18: 1 \omega 7 \mathrm{c}$ & $3 \cdot 5$ & $3 \cdot 3$ \\
\hline Total & 100 & 100 \\
\hline
\end{tabular}

${ }^{*}$ Grown at $12^{\circ} \mathrm{C}$ for 4 weeks on marine agar. tr: $\% \leq 0.5 \%$ total area. 
Table 2 Chemical analysis of exopolysaccharides from two Antarctic bacterial marine isolates ( $\mathrm{g} \cdot 100 \mathrm{~g}^{-1}$ total EPS)

\begin{tabular}{lllll}
\hline Isolate & $\begin{array}{l}\text { Uronic } \\
\text { acids (\%) }\end{array}$ & $\begin{array}{l}\text { Neutral } \\
\text { sugars (\%) }\end{array}$ & $\begin{array}{l}\text { Proteins } \\
(\%)\end{array}$ & $\begin{array}{l}\text { Sulphates } \\
(\%)\end{array}$ \\
\hline CAM025 & 22 & 74 & 2 & 5 \\
CAM036 & 25 & 50 & 3 & 5 \\
\hline
\end{tabular}

Table 3 Molar ratios of EPS monosaccharides determined by gas chromatography-flame ionization detection (GC-FID) analysis after acid methanolysis and trimethylsilyl derivatization

\begin{tabular}{lcl}
\hline & \multicolumn{2}{l}{ Isolate } \\
\cline { 2 - 3 } Monosaccharides & CAM025 & CAM036 \\
\hline Ara & $1 \cdot 0$ & $1 \cdot 0$ \\
Rib & $0 \cdot 3$ & $0 \cdot 0$ \\
Rha & $1 \cdot 1$ & $0 \cdot 0$ \\
Fuc & $0 \cdot 4$ & $0 \cdot 0$ \\
Gal A & $6 \cdot 4$ & $7 \cdot 2$ \\
Man & $0 \cdot 3$ & $5 \cdot 8$ \\
Gal & $1 \cdot 3$ & $0 \cdot 4$ \\
Glc & $12 \cdot 8$ & $6 \cdot 1$ \\
Gal N Ac & $0 \cdot 1$ & $2 \cdot 6$ \\
\hline
\end{tabular}

Values have been normalized to Ara $=1.0 \mathrm{Ara}$, arabinose; Rib, ribose; Rha, rhamnose; Fuc, fucose; Xyl, xylose; Gal A, galacuronic acid; Glc A, glucuronic acid; Man, mannose; Gal, galactose; Glc, glucose; Gal N Ac, N-acetyl-galactosamine. 